\title{
Activation in M1 but not M2 Macrophages Contributes to Cardiac Remodeling after Myocardial Infarction in Rats: a Critical Role of the Calcium Sensing Receptor/ NRLP3 Inflammasome
}

\author{
Wenxiu Liu Xin Zhang Meng Zhao Xiaohui Zhang Jinyu Chi Yue Liu \\ Fang Lin Yu Fu Dandan Ma Xinhua Yin \\ Department of Cardiology, First Affiliated Hospital of Harbin Medical University, Harbin, P.R. China
}

\section{Key Words}

Myocardial infarction - Macrophage - Calcium sensing receptor $\cdot$ NLRP3 inflammasome • Cardiac remodeling

\begin{abstract}
Aims: Macrophage $(\mathrm{M} \Phi)$ infiltration during myocardial infarction (MI) amplifies cardiac inflammation and remodeling. We investigated whether activation of the NRLP3 inflammasome by a calcium sensing receptor (CaSR) in MФ subsets contributes to cardiac remodeling following MI. Methods and Results: Infiltrated MФ exhibited biphasic activation after MI; M1MФ peaked at MI 3d and decreased until MI $14 \mathrm{~d}$, whereas M2MФ peaked at MI $7 \mathrm{~d}$ and decreased at MI $14 \mathrm{~d}$ as shown via immunohistochemistry. IL-1 $\beta$ co-infiltrated with both M1M $\Phi$ and $M 2 M \Phi$; IL-1 $\beta$ exhibited the same infiltrating tendency as M1M $\Phi$, which was detected by immunohistochemistry. Increasing ventricular fibrosis was confirmed by Masson staining. CaSR and NLRP3 inflammasome in the MI group were upregulated in MФ subsets in myocardium and peritoneal $M \Phi(p-M \Phi)$ compared with the sham groups which were detected by immunofluorescence and western blotting. CaSR-activated NLRP3 inflammasome played a role in $\mathrm{M} 1 \mathrm{M} \Phi$ via PLC-IP ${ }_{3}$ but did not play a role in $\mathrm{M} 2 \mathrm{M} \Phi$ which were polarized by the THP-1 as shown by western blotting and intracellular calcium measurement. CaSR/NLRP3 inflammasome activation in M1MФ led to the following effects: upregulated $\alpha$-sma, MMP-2 and MMP-9, and collagen secretion; and downregulated TIMP-2 in cardiac fibroblasts via IL$1 \beta-I L-1 R I$, which was detected by coculturing M1MФ and cardiac fibroblasts. Conclusions: We suggest that the CaSR/NLRP3 inflammasome plays an essential role via the PLC-IP ${ }_{3}$ pathway in M1MФ to promote cardiac remodeling post-MI in rats, including accelerated cardiac fibroblast phenotypic transversion, increased collagen and extracellular matrix (ECM) secretion; however, the CaSR/NLRP3inflammasome does not play a role in this process in M2MФ.
\end{abstract}

Copyright (c) 2015 S. Karger AG, Basel 


\section{Cellular Physiology Cell Physiol Biochem 2015;35:2483-2500

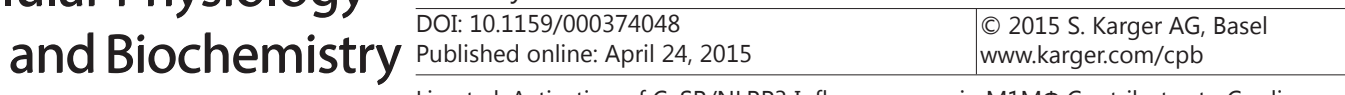 \\ Liu et al: Activation of CaSR/NLRP3 Inflammasome in M1MФ Contributes to Cardiac Remodeling after MI}

\section{Introduction}

Myocardial infarction (MI) induces a sterile inflammatory response, which is characterized by the recruitment and activation of innate and adaptive immune cells, and is a prerequisite for healing and scar formation $[1,2]$. Macrophages $(M \Phi)$ are the primary responder cell types involved in the regulation of post-MI wound healing [3]. The following two major $M \Phi$ subsets exist: classical activated $M \Phi(M 1 M \Phi)$ and alternative activated $M \Phi$ (M2MФ). These cells remove necrotic cardiomyocytes and secrete cytokines such as IL$1 \beta$, and chemokines and modulate phases of the angiogenic response [4]. Plasma IL-1 $\beta$ is significantly increased in patients with MI compared with healthy individuals [5]. In addition, IL-1 $\beta$ is upregulated in MI compared with sham rats [6]. IL-1 $\beta$ drives the local inflammatory reaction [7] and increases cardiac remodeling [8], cardiac enlargement [9] and dysfunction following MI [10].

The NLRP3 inflammasome is a host inflammatory signaling complex involved in the responses to pathogens and endogenous danger signaling that activates pro-caspase- 1 (Pro-Casp-1) and induces processing of caspase-1 (Casp-1) dependent inflammatory cytokines (particularly IL-1 $\beta$ ). The NLRP3 inflammasome exerts its biological functions via inflammatory cytokines, including IL-1 [11], and is expressed in immune [12] and nonimmune cells [13]. However, the expression of NLRP3 inflammasome, the mechanism of NLRP3 inflammasome activation in MФ subsets, and its function post-MI have not been clarified.

CaSR, a member of the 7-transmembrane receptor super family [14], has pleiotropic effects, including alterations in cellular proliferation and apoptosis $[15,16]$. CaSR activates the phospholipase C (PLC) signaling pathway, which results in an increase in inositol phosphate (IP) accumulation and $\mathrm{Ca}^{2+}$ mobilization. Administration of a CaSR activator induces myocardial fibrosis compared with sham rats [17]. Although the functional expression of CaSR promotes the secretion of IL-1 $\beta$ in differentiated THP- 1 cells [18] and CaSR knockdown reduces inflammasome activation in response to known NLRP3 activators [19]. Whether CaSR expression and activation of the NLRP3 inflammasome in MФ subsets are involved in cardiac remodeling post-MI has not been reported.

In our study, we utilized a rat MI model to elucidate the expression of CaSR and the NLRP3 inflammasome in MФ subsets at different time points during MI. Furthermore, the activation of CaSR/NLRP3 inflammasome in M $\Phi$ subsets was detected by polarized THP-1. Finally, we tested the effects of the CaSR/NLRP3 inflammasome in M $\Phi$ subsets on cardiac fibroblasts via coculturing.

\section{Materials and Methods}

\section{Experimental MI model}

Rats (Wistar, male, $200 \pm 20 \mathrm{~g}$ ) were subjected to a permanent ligation of the left anterior descending (LAD) or a sham operation without ligation as previously described [20]. In brief, the rats were lightly anesthetized with $10 \%$ chloral hydrate $(0.3 \mathrm{ml} / 100 \mathrm{~g})$, intubated, and then ventilated with a rodent respirator. The chest cavity was opened via left thoracotomy to expose the heart to enable the LAD to be visualized and permanently ligated with a 4-0 silk suture at the site of its emergence from the left atrium. The rats that died during recovery from anesthesia were excluded from the analysis. The sham-operated animals underwent the same procedure without LAD ligation. After the operation, the rats were randomly divided into sham $3 d(n=12), 7 d(n=14)$, and $14 d(n=13)$ and MI $3 d(n=15), 7 d(n=20)$ and $14 d(n=18)$ groups. At the pre-determined time points (d 3, 7 and 14), the surviving animals were sacrificed, and their hearts and p-MФ were quickly excised. The hearts were rapidly frozen in liquid nitrogen for next studies. All experimental procedures were approved by the Institutional Animal Care and Use Committee of Harbin Medical University, PR China.

Masson staining

The hearts were placed in $4 \%$ buffered paraformaldehyde at $\mathrm{pH} 7.0$ and fixed for $24 \mathrm{~h}$ at room temperature. The tissue was then embedded, sectioned $(4 \mu \mathrm{m})$, and stained with Masson before the 


\section{Cellular Physiology Cell Physiol Biochem 2015;35:2483-2500 \begin{tabular}{ll|l} 
DOI: 10.1159/000374048 & $\begin{array}{l}\text { C) } 2015 \text { S. Karger AG, Basel } \\
\text { www.karger.com/cpb }\end{array}$ \\
\hline
\end{tabular} \\ Liu et al: Activation of CaSR/NLRP3 Inflammasome in M1MФ Contributes to Cardiac Remodeling after MI}

samples were viewed under light microscopy (Olympus BX60, Beijing, China). Ten microscopic fields $(\times 400$ magnification) of each LV were randomly chosen to calculate the collagen area.

\section{Immunohistochemistry}

To determine the infiltration of the MФ subsets, IL-1 $\beta$ and CaSR, immunohistochemistry was performed in paraffin sections using a microwave-based antigen retrieval method [21]. The antibodies used in this study were as follows: CD11b (1:100, Abcam), CD206 (1:200, Santa Cruz), IL-1ß (1:100, Santa Cruz) and CaSR (1:100, San Antonia). The positive cells per square millimeter for CD11b, CD206 and IL-1 $\beta$ were counted under a $\times 40$ power field of microscope in five random areas of $\mathrm{LV}$ tissues as previously described [22].

\section{Immunofluorescence}

For the characterization of MФ subset-specific expression of the CaSR and NLRP3 inflammasome, the colocalization of the MФ subsets and IL-1 $\beta$, an immunofluorescence technique was employed. After antigen retrieval, the slides were incubated with primary antibody for CD11b (1:100), CD206 (1:100), CaSR (1:100), NLRP3 (1:100, Abcam), ASC (1:100, Abcam), Casp-1 (1:100, Abcam) and IL-1ß (1:100) overnight at $4^{\circ} \mathrm{C}$. Anti-goat, anti-mouse or anti-rabbit FITC or TRITC-conjugated secondary antibody (1:100, Invitrogen) was applied for $2 \mathrm{~h}$ at $37^{\circ} \mathrm{C}$. Counterstaining was performed with DAPI at 1:20,000 for $5 \mathrm{~min}$, and the slides were coverslipped with SlowFade Antifade (both Invitrogen). Negative controls with nonspecific IgGs were run in parallel. Images were acquired with an IX70 microscope and MagnaFire 1.1 software (both Olympus) using a $\times 400$ magnification. Color composite images were generated with Image Pro-plus software.

\section{Isolation of Rat $p-M \Phi$}

Rat p-MФ were isolated according to the previously described method [23], with some modifications. Sham and MI rats of different time point and normal rats were anesthetized followed by cervical dislocation. The rats were placed supine on the table and obtained by sterile lavage of the peritoneal cavity with cold PBS. Then the cells were plated into $60 \mathrm{~mm}$ diameter culture dishes contained $3 \mathrm{ml}$ DMEM. The adhered cells were collected after $2 \mathrm{~h}$ adherence for CaSR and NLRP3 inflammasome detection and polarization for coculture.

\section{Polarization of THP-1-differentiated $M \Phi$ and rat $p-M \Phi$}

THP-1 cells which were kindly given as a present from Doctor Xu Haobo were maintained in RPMI 1640 (Thermo Scientific) supplemented with 10\% FBS (GIBCO), penicillin (100U $\mathrm{ml}^{-1}$ ), and streptomycin $\left(100 \mathrm{mg}^{*} \mathrm{ml}^{-1}\right)$ at $\mathrm{pH} 7.4,37^{\circ} \mathrm{C}$ in a $5 \% \mathrm{CO}_{2}$ atmosphere. The THP- 1 cells (seeded at $2 \times 10^{6} \mathrm{cells} / \mathrm{cm}^{2}$ ) were differentiated into MФ using 100nM PMA (Sigma Chemical) and polarized according to the method of Tjiu et al. with several modifications [24]. For M1MФ polarization, the cells were treated with PMA for $6 \mathrm{~h}$ and then cultured with PMA plus LPS (10ng' $\mathrm{ml}^{-1}$, Sigma Chemical) and human IFN- $\gamma$ (20ng $\mathrm{ml}^{-1}$, Peptrotech) for an additional $42 \mathrm{~h}$. For M2MФ polarization, the cells were treated with PMA for $6 \mathrm{~h}$ and then cultured with PMA plus human IL-4 (20ng' $\mathrm{ml}^{-1}$, Peptrotech) and human IL-13 (20ng $\mathrm{ml}^{-1}$, Peptrotech) for an additional $42 \mathrm{~h}$. The control MФ were differentiated from THP-1 cells by incubation with PMA for 48h [24]. The protocol of rat $\mathrm{p}-\mathrm{M} \Phi$ polarization was as follows: for M1 polarization, $\mathrm{p}-\mathrm{M} \Phi$ were treated with LPS $\left(10 \mathrm{ng}^{\cdot} \mathrm{ml}^{-1}\right)$ and rat IFN- $\gamma$ (20ng $\mathrm{ml}^{-1}$, Peprotech) for an additional 24h. For M2 polarization, p-M $\Phi$ were treated with rat IL-4 (20ng' $\mathrm{ml}^{-1}$, Peptrotech) and IL-13 (20ng' $\mathrm{ml}^{-1}$, Peptrotech) for an additional $24 \mathrm{~h}$.

\section{NLRP3 inflammasome activation or inhibition}

Inflammasome activation and inhibition experiments in $\mathrm{M} 1 \mathrm{M} \Phi$ or $\mathrm{M} 2 \mathrm{M} \Phi$ were performed according to previously described methods [25], with several modifications. M1MФ or M2M $\left(1 \times 10^{6}\right.$ cells/well $)$ were plated in $60 \mathrm{~mm}$ diameter culture dishes and then primed with $1 \mathrm{ug}^{\prime} \mathrm{ml}^{-1} \mathrm{LPS}$ in RPMI 1640 containing $10 \%$ FBS, and antibiotics. For NLRP3 inflammasome activation, the medium was replaced with RPMI 1640 medium supplemented with various concentration $\mathrm{GdCl}_{3}$ and $\mathrm{CaCl}_{2}$ (Cayman Chemical a specific activator of CaSR.) and finally $200 \mu \mathrm{M} \mathrm{GdCl}_{3}$ and $10 \mathrm{mM} \mathrm{CaCl}_{2}$ were used to induce the highest Casp- 1 and IL-1 $1 \beta$. For the inhibition of inflammasome activation [19] LPS-primed M1MФ or M2MФ were pretreated with NPS2390 (10mM, Cayman Chemical, a specific inhibitor of CaSR), Z-YVAD-FMK (YVAD-FMK; $1 \mu$ M, Enzo Life Science, a specific inhibitor of Casp-1), U73122 (5 $\mu$ M, Sigma Chemical, a special inhibitor of PLC), thapsigargin (TG; 10 


\section{Cellular Physiology Cell Physiol Biochem 2015;35:2483-2500 \begin{tabular}{ll|l}
\cline { 2 - 2 } and Biochemistry & $\begin{array}{l}\text { DOI: 10.1159/000374048 } \\
\text { Published online: April 24, 2015 }\end{array}$ & $\begin{array}{l}\text { O 2015 S. Karger AG, Basel } \\
\text { www.karger.com/cpb }\end{array}$ \\
\cline { 2 - 3 }
\end{tabular} \\ Liu et al: Activation of CaSR/NLRP3 Inflammasome in M1MФ Contributes to Cardiac Remodeling after MI}

$\mu \mathrm{M}$, Sigma Chemical, an endoplasmic reticulum (ER) ATP-ase inhibitor) and 2-aminoethyl diphenylborinate (2-APB; $10 \mu \mathrm{M}$, Sigma Chemical, an $\mathrm{IP}_{3}$ receptor-specific inhibitor) were added media for $30 \mathrm{~min}$, all the inhibitors were detected for various concentration to identify proper dose. In order to examine the role of CaSR in priming, the polarized $\mathrm{M} 1 \mathrm{M} \Phi$ were exposed to $\mathrm{GdCl}_{3}$ and $\mathrm{CaCl}_{2}$ with or without the LPS priming. After $24 \mathrm{~h}$ of treatment, supernatants (SN) and cell lysates (Lys) were collected for immunoblot analysis. And the rat $\mathrm{p}-\mathrm{M} \Phi$ polarized M1MФ SN were cocultured with cardiac fibroblasts for an additional $24 \mathrm{~h}$.

\section{IL-1 $\beta$ concentration measurement}

IL-1 $\beta$ in the cell SN was measured using an ELISA kit (R\&D Systems, Minneapolis, MN, USA) following the manufacturer's instructions [21].

\section{Intracellular calcium ([C $\left.\left.\mathrm{Ca}^{2+}\right]_{i}\right)$ measurement}

M1MФ were loaded with $10 \mu \mathrm{M}$ Flou-3/AM (Sigma Chemical) at $37^{\circ} \mathrm{C}$ for $30 \mathrm{~min}$ in HEPES buffered saline, and groups of 5 to 8 cells were monitored using an inverted Olympus IX-70 microscope. Cells were randomly divided into control, $\mathrm{GdCl}_{3}$ and intervention groups. Other intervention agents, such as NPS2390 $(10 \mu \mathrm{M}), \mathrm{NiCl}_{2}\left(100 \mu \mathrm{M}\right.$, Sigma Chemical, an inhibitor of $\mathrm{Na}^{+} / \mathrm{Ca}^{2+}$ exchanger $), \mathrm{CdCl}_{2}(20 \mu \mathrm{M}$, Sigma Chemical, an inhibiotr of L-type blocker), U73122 $(5 \mu \mathrm{M})$, TG $(10 \mu \mathrm{M})$ and 2-APB $(10 \mu \mathrm{M})$ were added media for $10 \mathrm{~min}$ prior to the addition of the activator $\mathrm{CaCl}_{2}$ or $\mathrm{GdCl}_{3}$. Spectrofluorometric measurements were collected using the Delta Scan System spectrofluorometer (Photon Technology), where the field was excited at 488nm, with emission at 530nm [26].

\section{Coculture of $M 1 M \Phi$ with cardiac fibroblasts}

Cardiac fibroblasts were isolated from 1-3 day-old neonatal rat hearts using a conventional method adopted by Ieda [27]. Briefly, after the hearts were digested by trypsin, the cells were suspended in DMEM with 10\% FBS and pre-cultured in a humidified incubator $\left(95 \%\right.$ air- $\left.5 \% \mathrm{CO}_{2}\right)$ for 90 min to obtain cardiac fibroblasts for their selective adhesion. Cardiac fibroblasts were cultured in non-serum DMEM for $12 \mathrm{~h}$ prior to the experiments. The M1MФ supernatant which were managed by the activator and inhibitor of CaSR were cocultured with cardiac fibroblasts for an additional $24 \mathrm{~h}$.

\section{Collagen assay}

After coculturing with the SN of activated M1MФ, the SN were collected to test the collagen levels. The collagen assay was performed using the Sircol collagen assay method (Biocolor) described by Sun et al. [28].

\section{Western blotting}

After treatment, the polarized THP-1 total cell Lys or SN and the cell Lys of coculture cells were collected to extract the protein with lysis buffer, which contained 1\% proteinase inhibitor solution. After complete homogenization on an ice rotator, the samples were centrifuged at $12,000 \mathrm{rpm}$ for $20 \mathrm{~min}$ at $4{ }^{\circ} \mathrm{C}$ to precipitate the cell debris. The SN were transferred into $4^{\circ} \mathrm{C}$ fresh tubes, and the protein concentrations were determined with a BCA Protein Assay Kit (Bio-Rad). The proteins were electrophoresed in 10\% SDSPAGE and transferred to PVDF membranes. After blocking with 5\% non-fat dry milk in PBS for $2 \mathrm{~h}$ at room temperature, the membranes were incubated with the following primary antibodies: CD11b $(1: 1,000)$, CD206 (1:1,000), CaSR (1:1,000), NLRP3 (1:1,000), ASC (1:1,000), Pro-Casp-1/Casp-1 (1:1,000), ProIL-1 $\beta /$ IL-1 $\beta$ (1:1,000), IL-1RI (1:1,000, Abcam), MMP-2 (1:500, Santa Cruz), MMP-9 (1:500, Santa Cruz), TIMP-2 (1:500, Santa Cruz), $\alpha$-sma (1:500, Abcam) and $\beta$-actin (1:500, Santa Cruz) at $4{ }^{\circ} \mathrm{C}$ overnight. After washing with TBST, the membranes were incubated with fluorescence-conjugated goat anti-mouse or antirabbit IgGs $(1: 10,000$, Rockland) at room temperature for $1 \mathrm{~h}$. Western blot bands were quantified using an Odyssey Infrared Imaging System (Gene Company) and Odyssey v3.0 software. The results were quantified with ImageJ software. The ratio for the protein examined was normalized against $\beta$-actin.

\section{Data analysis}

The data are presented as the mean \pm SEM. Statistical analyses were performed using one-way ANOVA followed by a Newman-Keuls multiple comparison test. $P<0.05$ was considered statistically significant. GraphPad Prism 5.0 (GraphPad Software) was used for statistical and graphical analysis. 


\section{Cellular Physiology Cell Physiol Biochem 2015;35:2483-2500

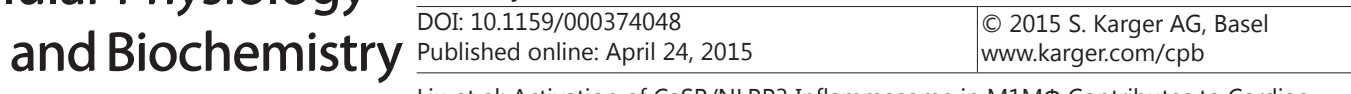 \\ Liu et al: Activation of CaSR/NLRP3 Inflammasome in M1MФ Contributes to Cardiac Remodeling after MI}

\section{Results}

Increased infiltration of $M \Phi$ subsets, IL-1 $\beta$ and myocardial fibrosis are induced in a rat $M I$ model

Successful establishment of the rat MI model was identified by an increased ST segment of ECG after LAD ligation and significantly increased serum TnT levels. A typical time course of MI, which was initiated by the accumulation of inflammatory cells and followed by the loss of cardiomyocytes and scar tissue formation detected by HE staining. Among the inflammatory cells, the $\mathrm{CD} 11 \mathrm{~b}^{+}$cells, namely, $\mathrm{M} 1 \mathrm{M} \Phi$, were increasingly infiltrated compared with the sham group; the percentage peaked at $3 \mathrm{~d}$, then decreased and was lowest at $14 \mathrm{~d}$ (Fig. $1 \mathrm{a}, \mathrm{b}$ ). In addition, few $\mathrm{CD}_{206^{+}}$cells represented the M2MФ invasion from MI 3d, whereas they were markedly increased until $7 \mathrm{~d}$ after MI and sustained at $14 \mathrm{~d}$ (Fig. $1 \mathrm{c}, \mathrm{d}$ ). These results demonstrated that $\mathrm{M} \Phi$ presented a time-dependent appearance of different activation types during MI. As shown in Fig. 1, IL-1 $\beta$ (Fig. 1 e, f) infiltrated after MI and sustained until 14d. To test the hypothesis that NLRP3 inflammasomes were activated in the $\mathrm{M} \Phi$ subsets after MI, we first colocalized M1MФ, M2M $\Phi$ and IL-1 $\beta$ in the peak infiltrating time points. The results demonstrated overlaps of both $M 1 M \Phi$ and $M 2 M \Phi$ with IL- $1 \beta$ in the granulation tissue and border zone $3 \mathrm{~d}$ and $7 \mathrm{~d}$ after MI (Fig. $1 \mathrm{i}, \mathrm{j}$ ). These results suggest that $\mathrm{M} 1 \mathrm{M} \Phi$ and $\mathrm{M} 2 \mathrm{M} \Phi$ may have secreted IL-1 $\beta$; however, the detailed mechanism is unknown. Furthermore, Masson staining indicated a significantly time-dependent increase in fibrotic tissue (Fig. $1 \mathrm{~g}, \mathrm{~h}$ ). Whether this fibrosis is associated with the infiltrated MФ subsets and these cytokines requires detection by coculturing.

\section{CaSR is upregulated in $M \Phi$ subsets after $M I$ in rats}

To determine whether CaSR is upregulated after MI in rats, we first performed immunohistochemisty to detect CaSR in cardiac tissue. The results indicated that the expression of CaSR significantly increased in the myocardium and infiltrated inflammatory cells compared with the sham groups(Fig. 2 a), and the results were confirmed by the expression of CaSR in cardiac tissue (Fig. 2 b, c). Furthermore, we tested the expression of CaSR on the p-M $\Phi$ which is most frequently isolated and stimulated as surrogate cells to examine the role of cytokines and growth factors on $M \Phi$ activation $[29,30]$, the results showed that CaSR was significantly increased in MI compared with sham groups in all predetermined time points (Fig. 2 b, d). At last, the results demonstrated that CaSR was upregulated in both CD11 b cells (M1MФ, Fig. 2 e) and CD206 ${ }^{+}$cells (M2MФ, Fig. 2 f) after MI compared with the sham-operated rats at all time points.

\section{NLRP3 inflammasome is upregulated in MФ subsets after MI in rats}

As the primary IL-1 $\beta$ processing inflammasome, NLRP3 inflammasome activation provoked substantial IL-1 $\beta$ secretion; therefore, we examined whether the NLRP3 inflammasome were upregulated after MI. We observed that components of NLRP3 inflammasome were significantly upregulated in p-MФ of MI compared to sham group (Fig. 2 a-d). Then, we detected its expression in cardiac tissue by double immunofluorescence. The results indicated that the NLRP3 inflammasome components were detected in both CD11 $\mathrm{b}^{+}$ cells (Fig. 3 e, f) and CD206 cells (Fig. 3 g, h), and the NLRP3 inflammasome staining was more prominently identified in the cytoplasm. The results also presented that there were less $\mathrm{CD} 206^{+} \mathrm{Casp}-1^{+}$cells compared with $\mathrm{CD} 206^{+} \mathrm{NLRP}^{+}$and $\mathrm{CD}^{206}{ }^{+} \mathrm{ASC}^{+}$cells. In M1MФ, both CaSR and the NLRP3 inflammasome staining peaked 3d after MI and subsequently decreased until 14d compared with the sham group (Fig. 2, 3). In M2M $\Phi$, both CaSR and the NLRP3 inflammasome staining increased from $3 \mathrm{~d}$, peaked at $7 \mathrm{~d}$ and were sustained until 14d after MI compared with the sham group (Fig. 2, 3). These results provide evidence for the co-activation of CaSR and the NLRP3 inflammasome after MI; however, whether the interaction between these factors plays a role in both $\mathrm{M} 1 \mathrm{M} \Phi$ and $\mathrm{M} 2 \mathrm{M} \Phi$ and whether the interaction contributes to cardiac remodeling after MI should be studied in vitro. 


\section{Cellular Physiology Cell Physiol Biochem 2015;35:2483-2500

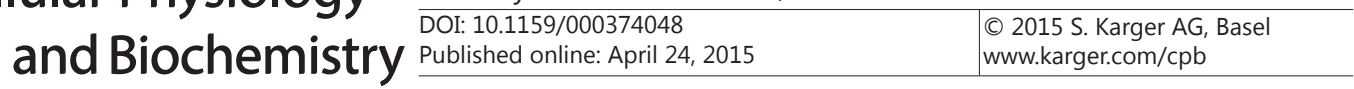 \\ Liu et al: Activation of CaSR/NLRP3 Inflammasome in M1MФ Contributes to Cardiac Remodeling after MI}

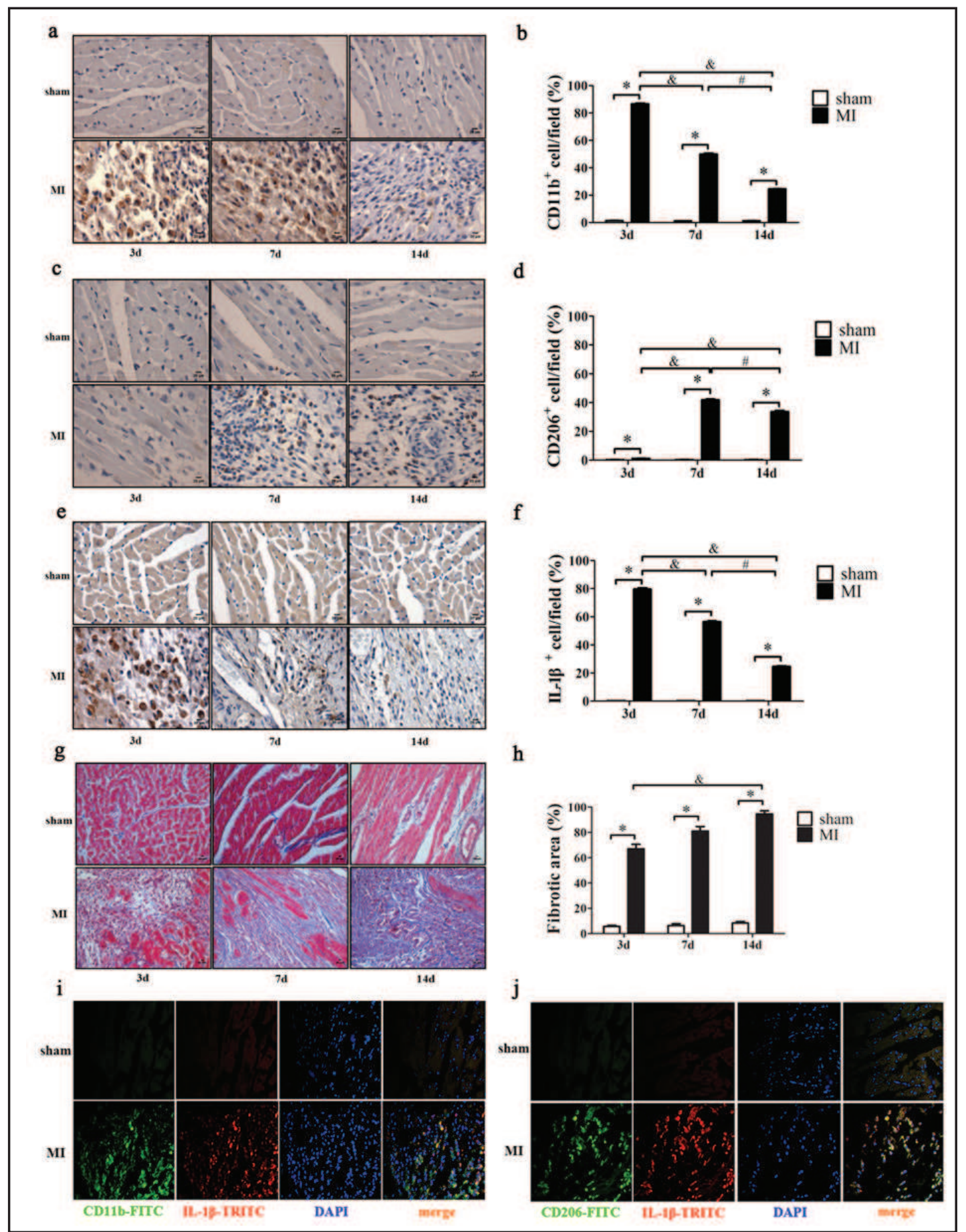

Fig. 1. Infiltration of $M \Phi$ subsets, IL-1 $\beta$ and fibrosis in sham and MI rat myocardiums. (a, c, e, g) Histochemical staining of CD11 $b^{+}, \mathrm{CD}_{206}{ }^{+}$and IL- $1 \beta^{+}$cells and Masson staining in the sham and MI rat myocardiums; original magnification $\times 400, \times 200$. (b, d, f, h) The bar graphs show the quantification of CD $11 \mathrm{~b}^{+}, \mathrm{CD}_{20} 06^{+}$and IL-1 $\beta^{+}$cells and the fibrotic area in the sham and MI rat myocardiums, $n=4 .{ }^{*}: p<0.05$, versus the sham group; \&: $\mathrm{p}<0.05$, versus the MI 3d group; \#: $\mathrm{p}<0.05$, versus the MI $7 \mathrm{~d}$ group. (i, j) Colocalization of CD11 $\mathrm{b}^{+}$and CD206 $6^{+}$with IL-1 $\beta^{+}$cells in the rat myocardiums at MI $3 \mathrm{~d}$ and MI $7 \mathrm{~d}$. Original magnification $\times 400$.

CaSR/NLRP3 inflammasome plays a role in $M 1 M \Phi$ but not $M 2 M \Phi$

To identify the interaction of the CaSR and NLRP3 inflammasome, we successfully polarized the M1MФ and M2M $\Phi$ via THP-1 by detecting the cell surface markers CD11b and KARGER 


\section{Cellular Physiology Cell Physiol Biochem 2015;35:2483-2500 \begin{tabular}{l|l}
\hline DOI: 10.1159/000374048 & O 2015 S. Karger AG, Basel
\end{tabular} \\ Published online: April 24, 2015 www.karger.com/cpb \\ Liu et al: Activation of CaSR/NLRP3 Inflammasome in M1MФ Contributes to Cardiac Remodeling after MI}

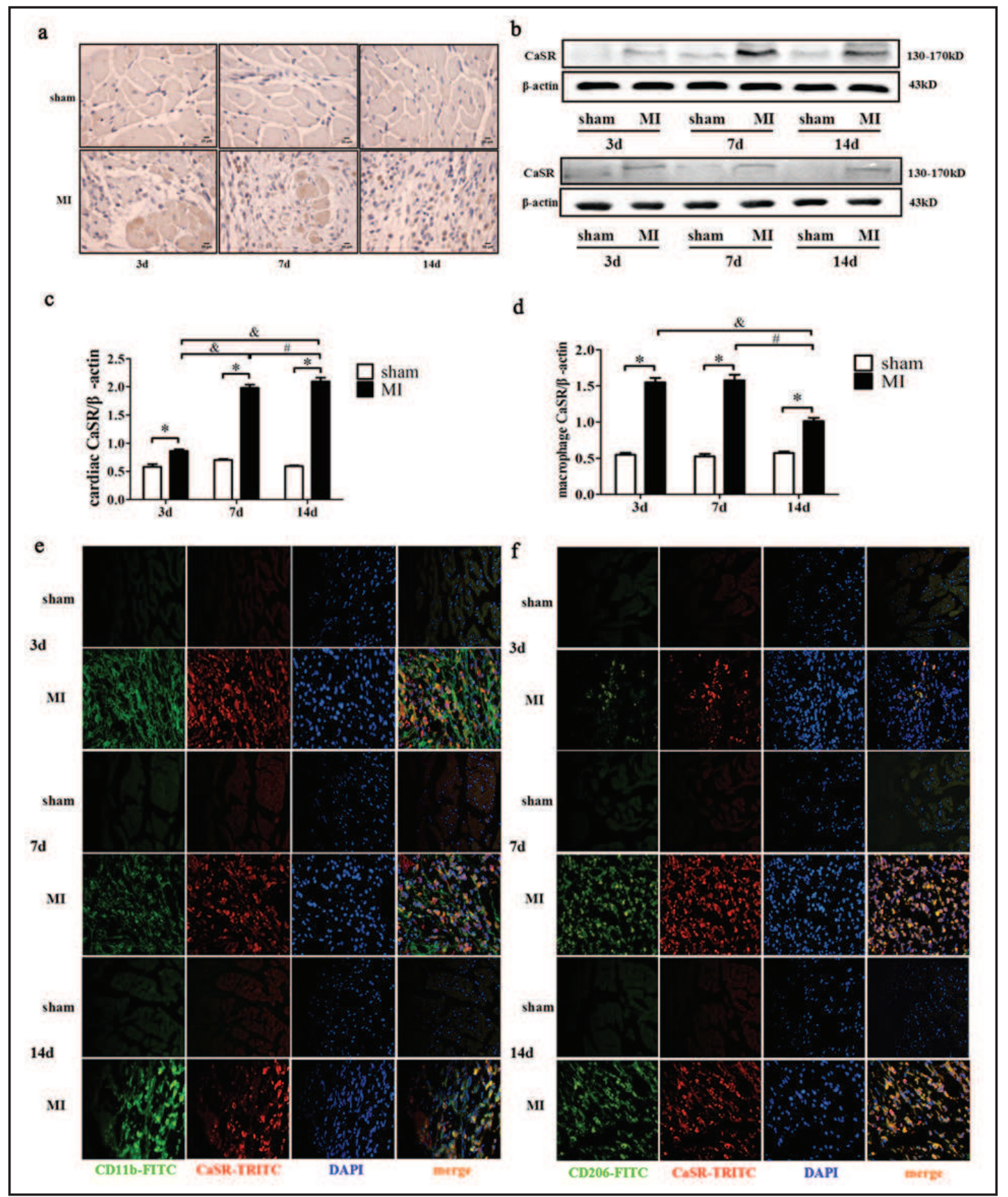

Fig. 2. Expression of CaSR in p-M $\Phi, C D 11 b^{+}$and $\mathrm{CD}_{206^{+}}$cells in sham and MI rat myocardiums. (a) Immunohistochemisty of CaSR in rat myocardiums. original magnification $\times 400$. (b) Expression of CaSR in rat myocardiums and $\mathrm{p}-\mathrm{M} \Phi$. The upper panel: CaSR expression on rat myocardium; the lower panel: CaSR expression on rat p-MФ. (c, d) The graphs show the mean \pm SEM from three independent experiments. *: $\mathrm{p}<0.05$, versus the sham group; \&: $\mathrm{p}<0.05$, versus the MI $3 \mathrm{~d}$ group; \#: $\mathrm{p}<0.05$, versus the MI $7 \mathrm{~d}$ group. (e, f) Colocalization of $\mathrm{CD} 11 \mathrm{~b}^{+}$and $\mathrm{CD} 206^{+}$with $\mathrm{CaSR}^{+}$cells in the rat myocardiums post MI. Original magnification $\times 400$.

CD206. At first, the study was performed to exclude the priming role of CaSR in the NLRP3 inflammasome. The results demonstrated that the expression of Pro-IL-1 $\beta$ unchanged in the present of $\mathrm{CaCl}_{2}, \mathrm{GdCl}_{3}$ and NPS2390 without LPS priming (Fig. $4 \mathrm{~h}$, i). In addition, we also primed the M1M $\Phi$ with LPS before adding $\mathrm{GdCl}_{3}$ and $\mathrm{CaCl}_{2}$, this treatment augmented 


\section{Cellular Physiology Cell Physiol Biochem 2015;35:2483-2500

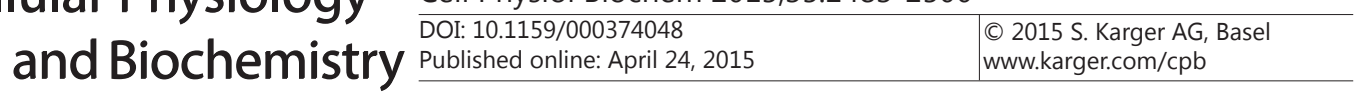 \\ Liu et al: Activation of CaSR/NLRP3 Inflammasome in M1MФ Contributes to Cardiac Remodeling after MI}

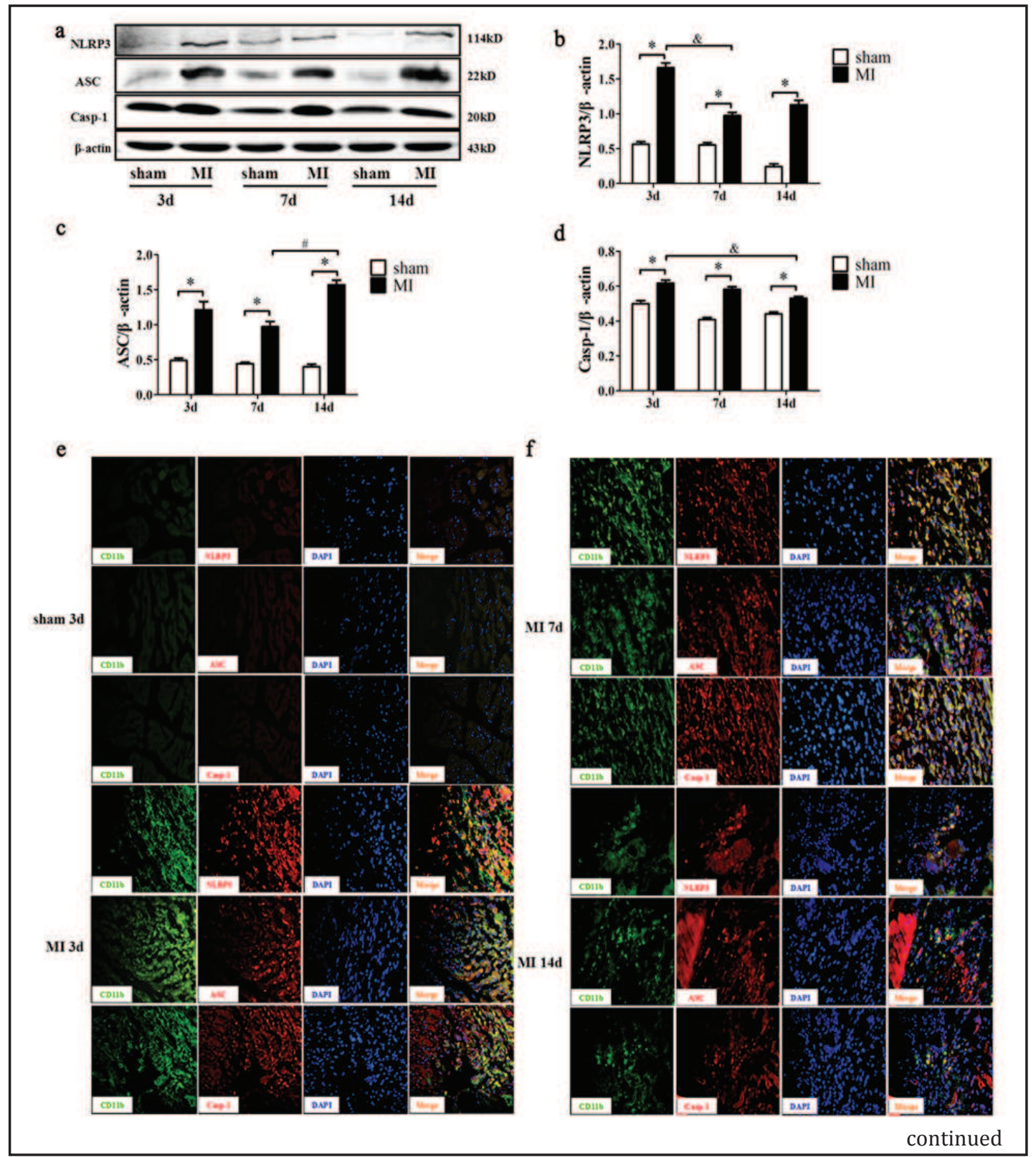

Fig. 3. Expression of the NLRP3 inflammasome in $\mathrm{p}-\mathrm{M} \Phi, \mathrm{CD} 11 \mathrm{~b}^{+}$and $\mathrm{CD} 206^{+}$cells in sham and MI rat myocardiums. (a) Expression of NLRP3 inflammasome in rat p-MФ and myocardiums. The upper panel: NLRP3 inflammasome expression on rat myocardium; the lower panel: NLRP3 inflammasome expression on rat p-МФ. (b, c, d) The graphs show the mean \pm SEM from three independent experiments. *: $p<0.05$, versus the sham group; \&: $\mathrm{p}<0.05$, versus MI 3 d group; \#: $\mathrm{p}<0.05$, versus the MI $7 \mathrm{~d}$ group. $(\mathrm{e}-\mathrm{h})$ Colocalization of $\mathrm{CD} 11 \mathrm{~b}^{+}$and $\mathrm{CD} 206^{+}$with components of NLRP3 inflammasome in the rat myocardiums post MI. Original magnification $\times 400$.

the release of IL-1 $\beta$ significantly, which increased the expression of Pro-IL-1 $\beta$ as well, and the inhibitor NPS2390 reversed this effect (Fig. 4 j-l). Then, in $\mathrm{M} 1 \mathrm{M} \Phi, \mathrm{GdCl}_{3}$ significantly increased the expression of NLRP3, ASC, Pro-Casp-1, Casp-1, and IL-1 $\beta$, whereas NPS2390 reversed these effects. These findings indicate that CaSR induced proteolytic processing of Casp-1 to regulate IL-1 $\beta$ secretion in our study (Fig. 4 a-f). We subsequently evaluated the role of the caspase-1-specific inhibitor YVAD-FMK in this pathway. YVAD-FMK inhibited the expression of Casp-1 and IL-1 $\beta$ but not CaSR, NLRP3 and ASC in THP-1-polarized M1MФ

\section{KARGER}




\section{Cellular Physiology Cell Physiol Biochem 2015;35:2483-2500

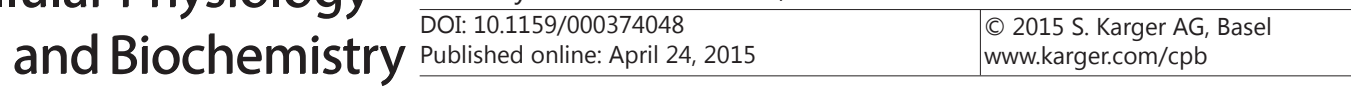 \\ Liu et al: Activation of CaSR/NLRP3 Inflammasome in M1MФ Contributes to Cardiac Remodeling after MI}

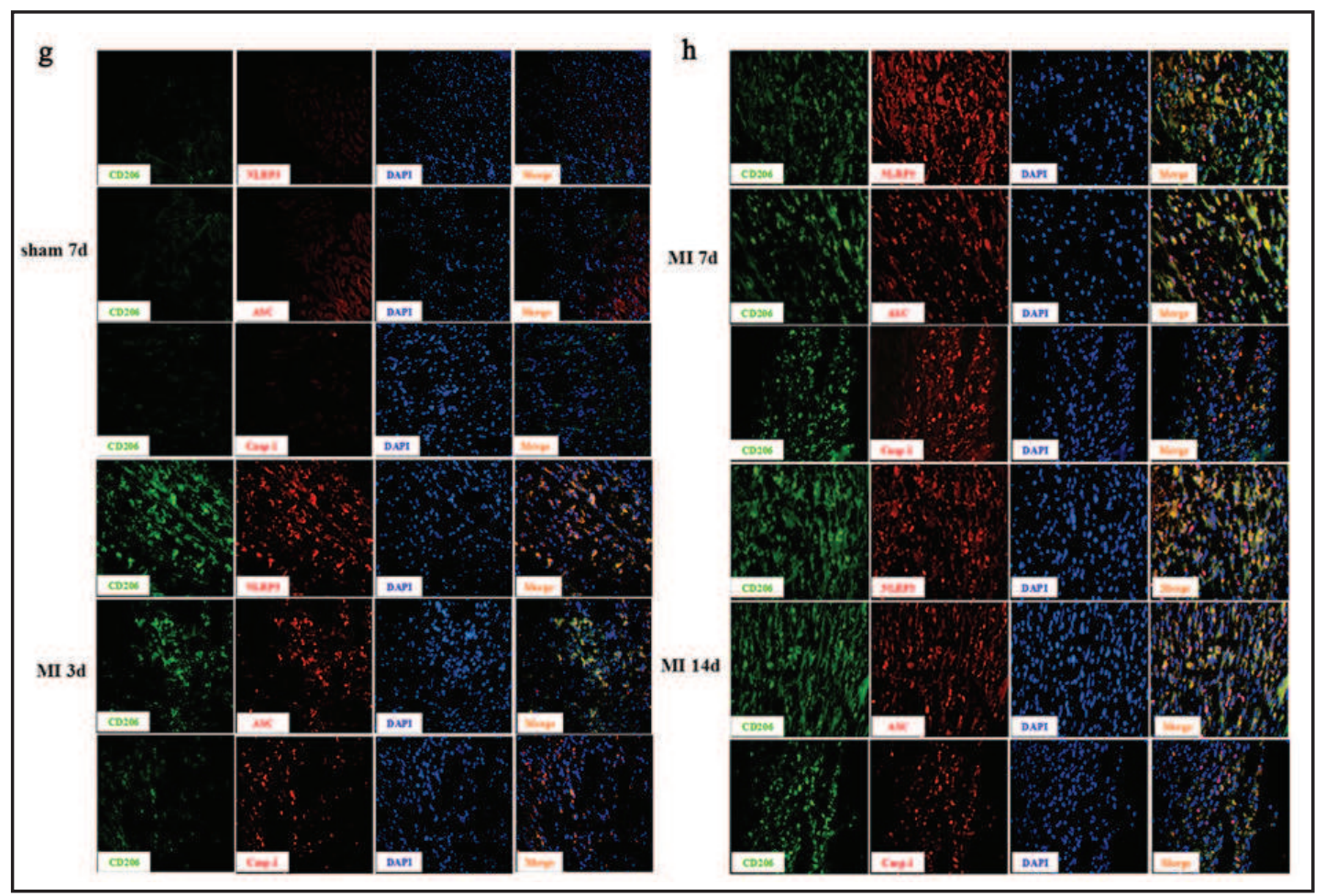

(Fig. 4 a-f). In $M 2 M \Phi$, although the $\mathrm{GdCl}_{3}$ significantly increased and the specific inhibitor significantly decreased the expression of CaSR, NLRP3 and ASC (Fig. 5 a-d), no Casp-1 and IL-1 $\beta$ expression were observed (Fig. 5 a, e, f). The expression of IL- $1 \beta$ was verified by ELISA assay, which was consistent with the western blotting results (Fig. 4 g, Fig. 5 g). These results indicated that CaSR upregulates NLRP3 inflammasome components in both M1M $\Phi$, although CaSR upregulates NLRP3 inflammasome components in M2MФ, the NLRP3 inflammasome function is inhibited in M2MФ. The mechanism of the interaction between CaSR/NLRP3 inflammasome and whether the interaction between them in $\mathrm{M} 1 \mathrm{M} \Phi$ contributes to cardiac remodeling should be verified.

\section{CaSR upregulates NLRP3 inflammasome through PLC-IP ${ }_{3}$ pathway in $M 1 M \Phi$}

To confirm that CaSR functionally regulates NLRP3 inflammasome by PLC-IP ${ }_{3}$ signaling, we detected that CaSR functionally regulates $\left[\mathrm{Ca}^{2+}\right]_{\mathrm{i}}$ in $\mathrm{M} 1 \mathrm{M} \Phi$ firstly. Cells were treated with $\mathrm{GdCl}_{3}, \mathrm{NiCl}_{2}$ and $\mathrm{CdCl}_{2}$ in the bath solution, and these management evoked a time-dependent increase in $\left[\mathrm{Ca}^{2+}\right]_{i^{*}}$ After pretreatment with NPS2390, $\left[\mathrm{Ca}^{2+}\right]_{i}$ was not significantly increased compared to administration of $\mathrm{GdCl}_{3}$ alone. Meanwhile, $\mathrm{M} 1 \mathrm{M} \Phi$ were pretreated for $10 \mathrm{~min}$ with U73122 followed by treating with $\mathrm{GdCl}_{3}$, which failed to elicit any increase of $\left[\mathrm{Ca}^{2+}\right]_{\mathrm{i}}$. Similar to U73122, preincubation of M1M $\Phi$ with TG for $10 \mathrm{~min}$, abolished the increase in $\left[\mathrm{Ca}^{2+}\right]_{\mathrm{i}}$. Pretreatment with 2-APB for 10 min eliminated the effect of $\mathrm{GdCl}_{3}$ on the induction of $\left[\mathrm{Ca}^{2+}\right]_{\mathrm{i}}$ release (Fig. 6 a). These results demonstrated that the activation of CaSR resulted in the $\left[\mathrm{Ca}^{2+}\right]_{\mathrm{i}}$ increase in M1M $\Phi$ via stimulation of the PLC-IP ${ }_{3}$ pathway.

Secondly, we tested the presence of CaSR, components of NLRP3 inflammasome, Casp1 and IL- $1 \beta$ in the presence of specific inhibitors of PLC-IP ${ }_{3}$ signaling. We observed that cells treated with U73122 blocked the presence of NLRP3 inflammasome, ASC, Casp-1and $\mathrm{L}-1 \beta$ in the SN of LPS-primed M1M $\Phi$ which were treated with $\mathrm{GdCl}_{3}$ but not the expression of CaSR (Fig. 6 b-g). Moreover, when LPS-primed M1M $\Phi$ were stimulated with $\mathrm{GdCl}_{3}$ in the presence of an $\mathrm{IP}_{3}$ receptor inhibitor 2-APB, all the NLRP3 inflammasome, Casp-1, and active IL-1 $\beta$ were inhibited except the CaSR (Fig. 6 b-g). Whereas, NLRP3 inflammasome activation was decreased in LPS-primed M1M $\Phi$ by treatment with TG which elevates $\left[\mathrm{Ca}^{2+}\right]_{\mathrm{i}}$ (Fig. 6 b-g). The expression of IL-1 $\beta$ was verified by ELISA assay, which was consistent with 


\section{Cellular Physiology Cell Physiol Biochem 2015;35:2483-2500 \begin{tabular}{l|l}
\hline DOI: 10.1159/000374048 & O 2015 S. Karger AG, Basel
\end{tabular} and Biochemistry Published online: April 24, 2015 www.karger.com/cpb \\ Liu et al: Activation of CaSR/NLRP3 Inflammasome in M1MФ Contributes to Cardiac Remodeling after MI}

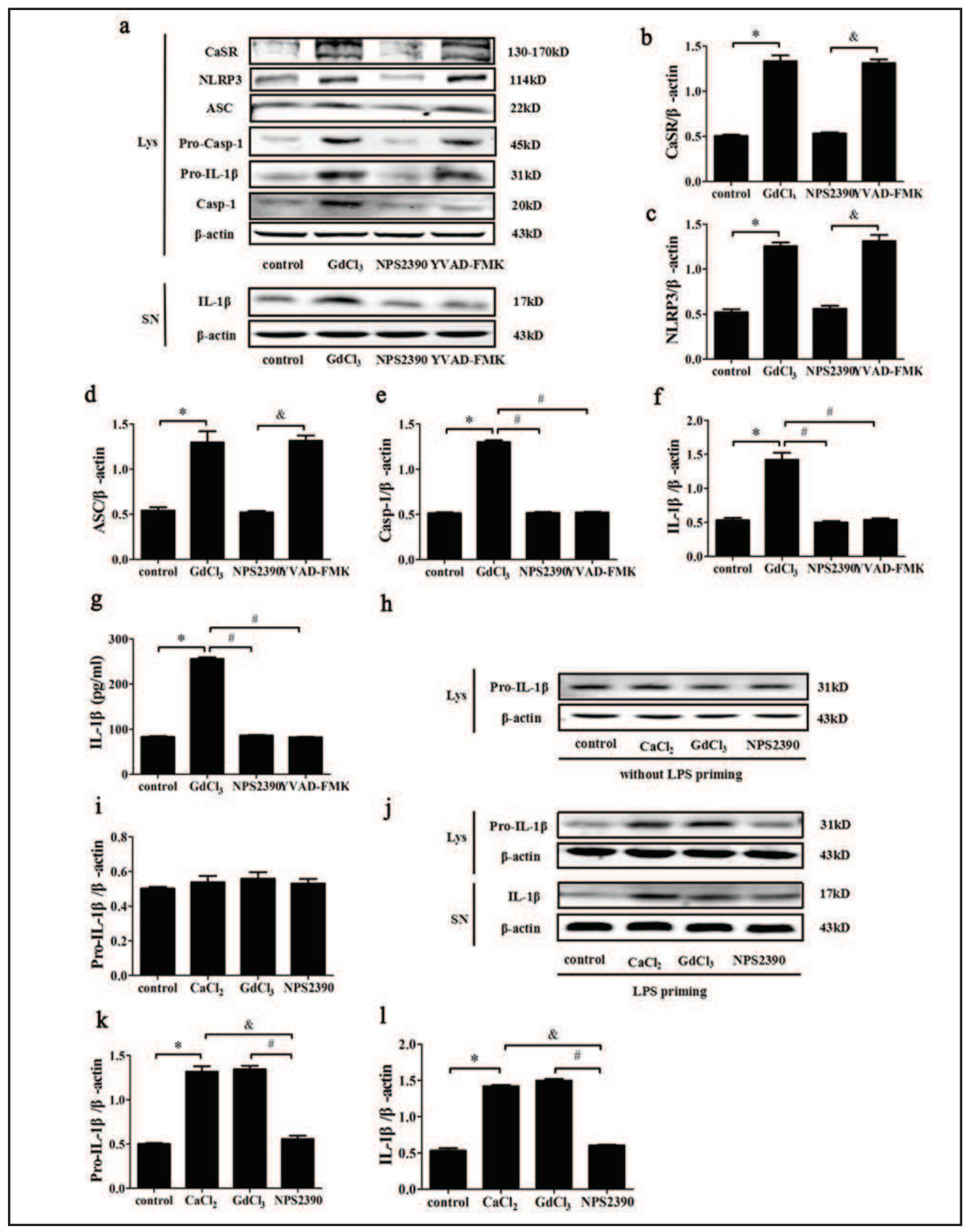

Fig. 4. Activation of the NLRP3 inflammasome by CaSR in M1MФ. (a) The expression of CaSR, NLRP3 inflammasome, Casp-1 and IL-1 $\beta$ in M1MФ. (h) The expression of Pro-IL-1 $\beta$ without LPS priming in M1MФ. (j) The expression of Pro-IL-1 $\beta$ and IL-1 $\beta$ with LPS priming in M1MФ. (b-f, i, k, l) The graphs show the mean \pm SEM from three independent experiments. *: p<0.05, versus the control group; \&: $p<0.05$, versus the NPS2390 or $\mathrm{CaCl}_{2}$ group; \#: $\mathrm{p}<0.05$, versus the $\mathrm{GdCl}_{3}$ group. (g) The IL- $1 \beta$ levels in the culture medium following different treatments were detected by ELISA. ${ }^{*} \mathrm{p}<0.05$ versus the control group, $\# \mathrm{p}<0.05$ versus the $\mathrm{GdCl}_{3}$ group.

western blotting results (Fig. $6 \mathrm{~h}$ ). Taken together, these data indicate that the interaction of the CaSR/NLRP3 inflammasome is mediated by the PLC-IP ${ }_{3}$ pathway. 


\section{Cellular Physiology Cell Physiol Biochem 2015;35:2483-2500

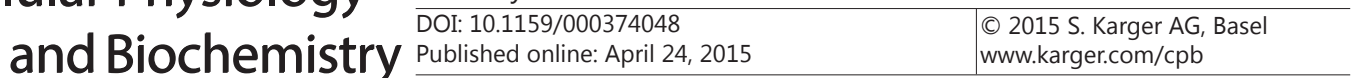 \\ Liu et al: Activation of CaSR/NLRP3 Inflammasome in M1M $\Phi$ Contributes to Cardiac Remodeling after MI}

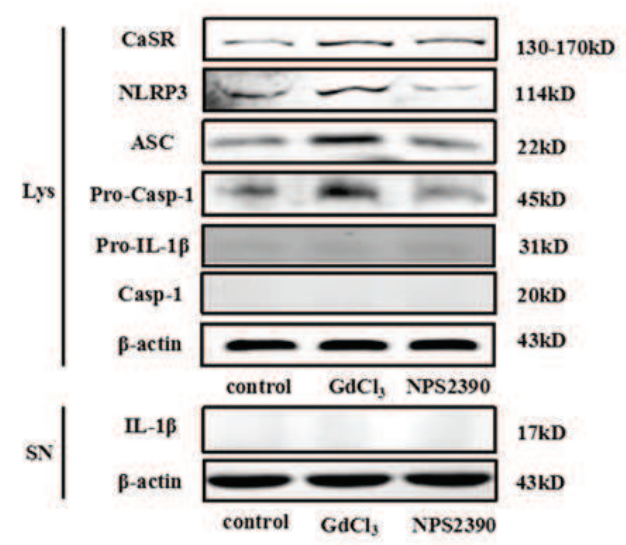

d

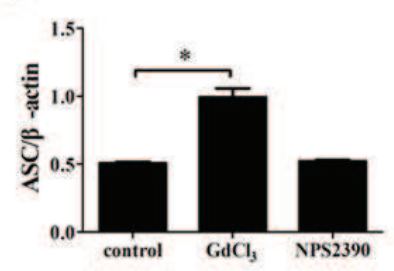

e

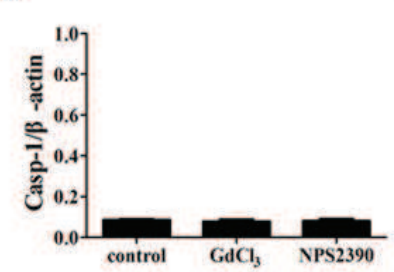

b

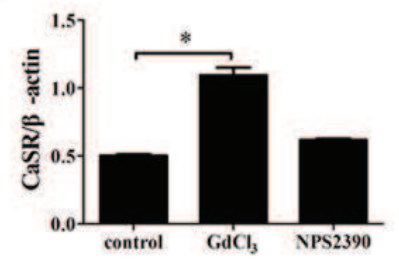

c

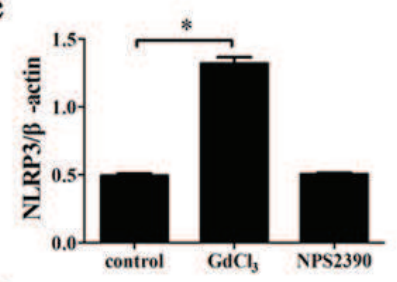

f

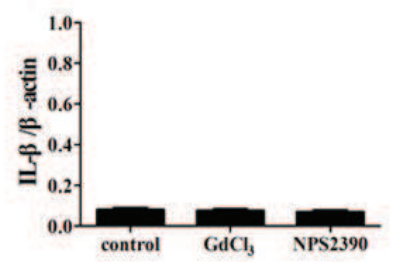

g

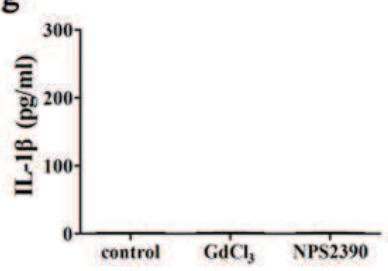

Fig. 5. The NLRP3 inflammasome is not activated by CaSR in M2MФ. (a) Expression of CaSR, , NLRP3 inflammasome, Casp-1 and IL-1 $\beta$ in M2MФ. (b-f) The graphs show the mean \pm SEM from three independent experiments. *: $\mathrm{p}<0.05$, versus the control group. (g) The IL-1 $\beta$ levels in the culture medium following different treatments were detected by ELISA.

CaSR/NLRP3 inflammasome in M1MФ contributes to the acceleration of the phenotypic switch, collagen and ECM secretion in cardiac fibroblasts

To confirm the activation effects of the CaSR/NLRP3 inflammasome in M1M $\Phi$ on cardiac fibroblasts, we cocultured the SN of p-M $\Phi$ polarized $\mathrm{M} 1 \mathrm{M} \Phi$ which were managed by the activator and inhibitor of CaSR with cardiac fibroblasts for $24 \mathrm{~h}$. The SN of the CaSR activator-managed $\mathrm{M} 1 \mathrm{M} \Phi$ displayed increased $\alpha$-sma expression in the cardiac fibroblasts (Fig. 7 a, b). This finding represents an important phenotypic switch marker from cardiac fibroblasts to myofibroblasts, which are known to be important for collagen deposition during scar formation after myocardial injury and are regarded as major contributors to scar formation by the indirect regulation of scar formation via the secretion of fibrogenic growth factors. The results indicated that the CaSR/NLRP3 inflammasome upregulated MMP-2 and -9 , downregulated TIMP-2 in supernatant-managed cardiac fibroblasts (Fig. 7 e-h) and promoted the secretion of collagen (Fig. $7 \mathrm{i}$ ), which contributed to cardiac remodeling. These functions of the activator were accompanied by upregulated IL-1R and were reversed by the CaSR inhibitor (Fig. 7 c, d). These results demonstrate that the CaSR/NLRP3 inflammasome in M1MФ contributes to acceleration of the phenotypic switch, collagen and ECM secretion of cardiac fibroblasts. 


\section{Cellular Physiology Cell Physiol Biochem 2015;35:2483-2500

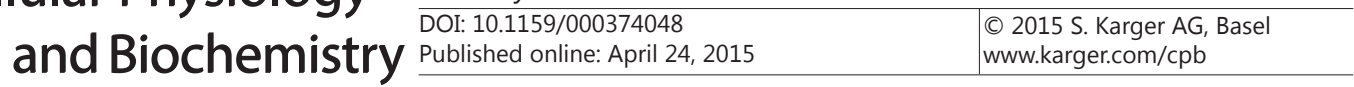 \\ Liu et al: Activation of CaSR/NLRP3 Inflammasome in M1MФ Contributes to Cardiac Remodeling after MI}

a

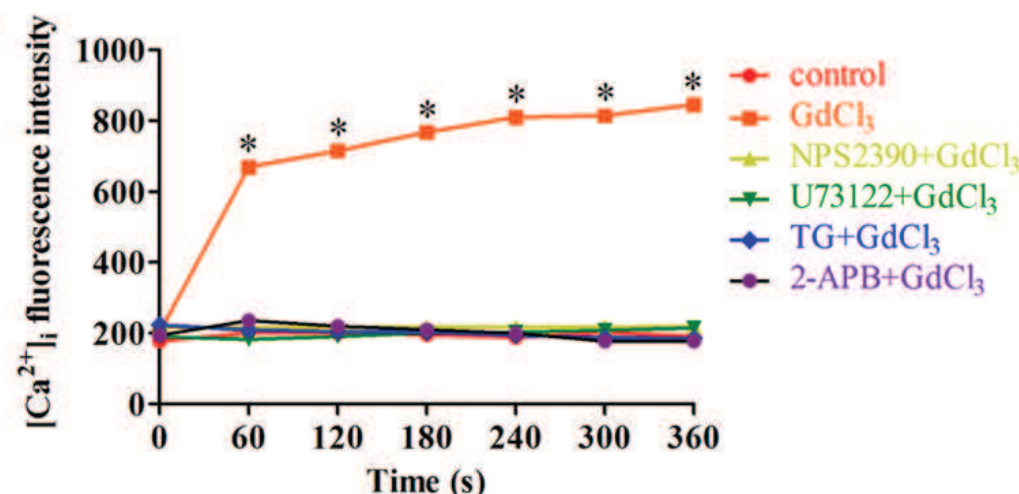

b

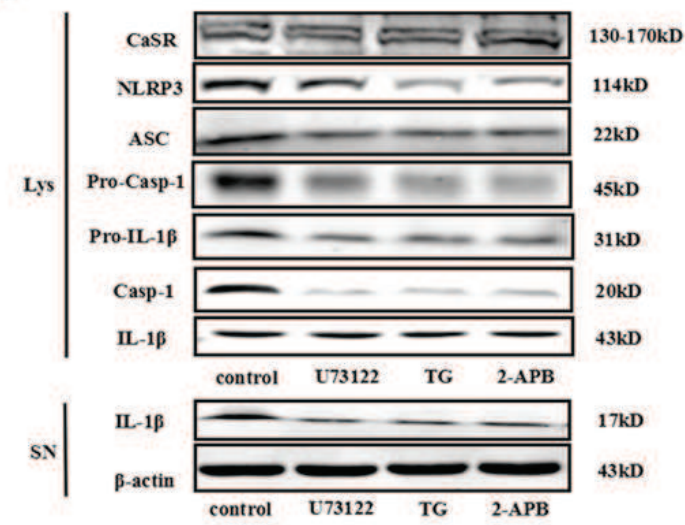

e

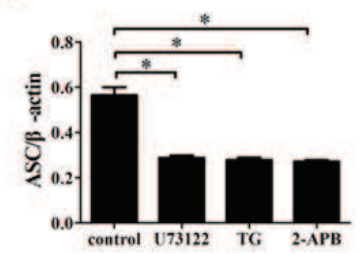

f

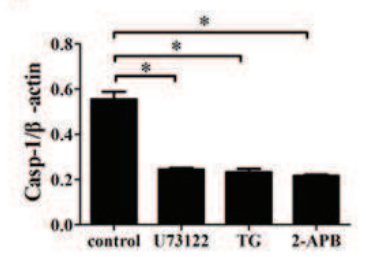

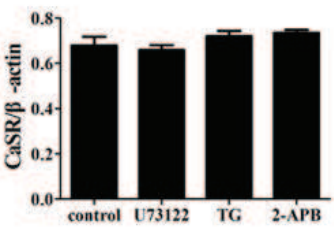

d

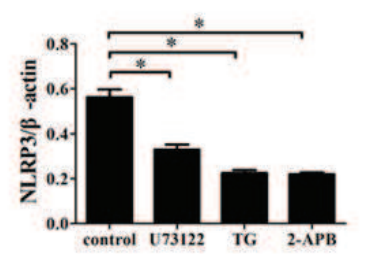

g

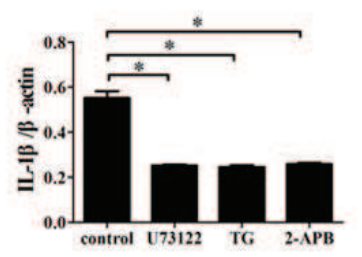

h

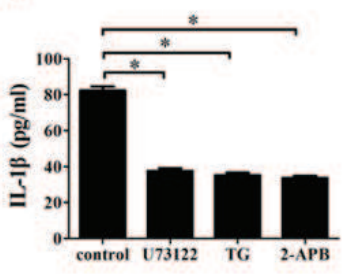

Fig. 6. CaSR/NLRP3 inflammasome played a role via the PLC-IP ${ }_{3}$ pathway in M1MФ. (a) CaSR activation induces $\mathrm{Ca}^{2+}$ release from the ER in the M1MФ. $(n=5-6),{ }^{*}: \mathrm{p}<0.05$, versus the other groups of the same time point. (b) Expression of CaSR, , NLRP3 inflammasome, Casp-1 and IL-1 $\beta$ in M1MФ after the inhibitors of PLC-IP ${ }_{3}$ pathway were used. (c-g) The graphs show the mean \pm SEM from three independent experiments. *: $\mathrm{p}<0.05$, versus the control group. (h) The IL-1 $\beta$ levels in the culture medium following different treatments were detected by ELISA. ${ }^{*} \mathrm{p}<0.05$ versus the control group.

\section{Discussion}

MI activates the innate immune system and induces a sterile inflammatory response, which is a prerequisite for healing and scar formation $[1,2]$. In the present study, we 


\section{Cellular Physiology Cell Physiol Biochem 2015;35:2483-2500

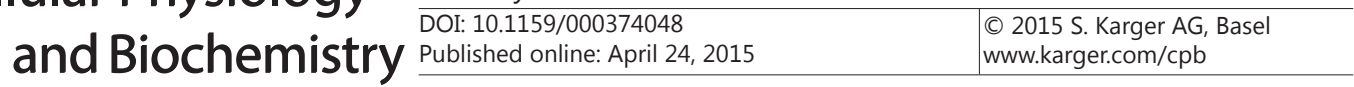 \\ Liu et al: Activation of CaSR/NLRP3 Inflammasome in M1MФ Contributes to Cardiac Remodeling after MI}

Fig. 7. Interaction between M1M $\Phi$ and cardiac fibroblasts. (a, c, e) The expression of $\alpha$-sma, IL-1R I, MMP-2, -9 , TIMP-2 after coculture with $\mathrm{M} 1 \mathrm{M} \Phi \mathrm{SN}$ for 24 h. ${ }^{*} \mathrm{p}<0.05$ versus the control group; \&: p<0.05, versus the $\mathrm{GdCl}_{3}$ group. (i) After coculture with M1MФ supernatants for $24 \mathrm{~h}$, the supernatants were collected and subjected to a Sircol collagen assay. \&: $p<0.05$, versus the $\mathrm{GdCl}_{3}$ group. a

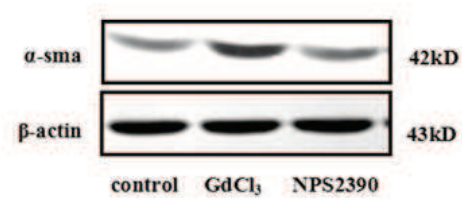

c

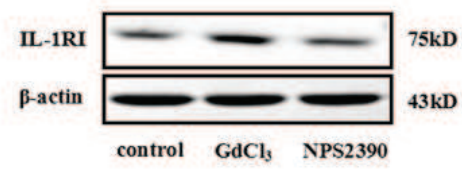

e

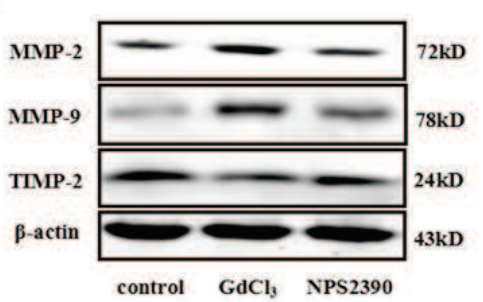

g

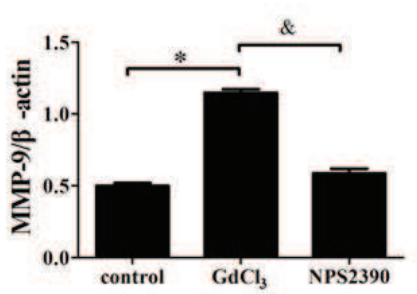

i

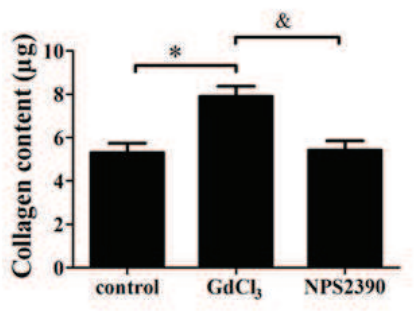

b
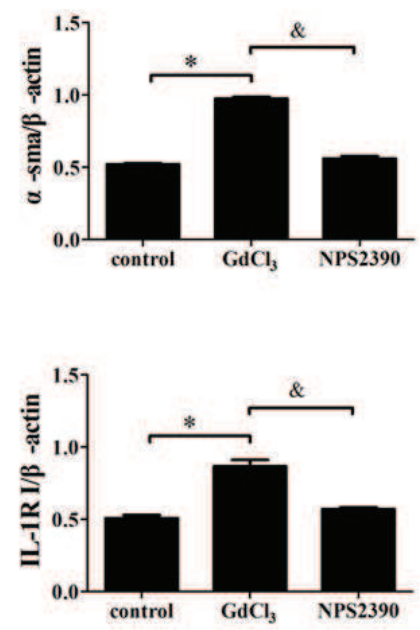

f

h

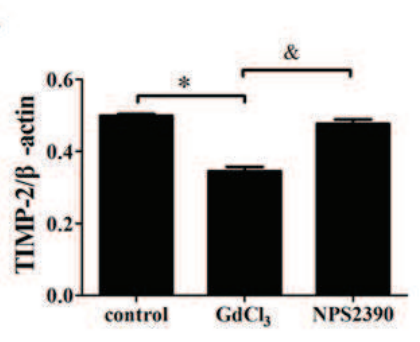

d

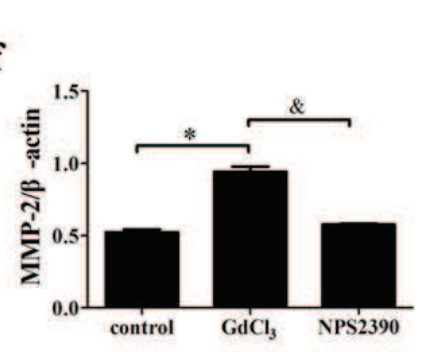

observed that MI induced myocardial inflammation and fibrosis. Furthermore, we were the first to identify both CaSR and NLRP3 inflammasome upregulation in p-MФ and MФ subsets in rat myocardium post-MI; the CaSR/NLRP3 inflammasome played a role via the PLC-IP pathway in $\mathrm{M} 1 \mathrm{M} \Phi$ but was inactive in the $\mathrm{M} 2 \mathrm{M} \Phi$. This process in $\mathrm{M} 1 \mathrm{M} \Phi$ accelerated cardiac fibroblast phenotypic transversion, collagen and ECM secretion via IL-1 $\beta$-IL-1RI. Thus, the activation of CaSR/NLRP3 inflammasome contributes to cardiac remodeling after MI.

Heterogeneous M $\Phi$ are classified into M1 and M2M $\Phi$ based on surface marker expression [4]. Consistent with previous reports [31], the infiltrating $M \Phi$ in this study exhibited biphasic activation after MI, with the first-responder M1M $\Phi$ and the late-responder M2M $\Phi$. The continuous infiltration of $\mathrm{M} \Phi$ accompanied by IL-1 $\beta$ and exacerbated fibrosis were observed in our study. Meanwhile, we demonstrated that both M1MФ and M2MФ coexpressed with 


\section{Cellular Physiology Cell Physiol Biochem 2015;35:2483-2500 \begin{tabular}{ll|l} 
and Biochemistry 10.1159/000374048 & $\begin{array}{l}\text { O 2015 S. Karger AG, Basel } \\
\text { www.karger.com/cpb }\end{array}$ \\
\cline { 2 - 3 }
\end{tabular} \\ Liu et al: Activation of CaSR/NLRP3 Inflammasome in M1MФ Contributes to Cardiac Remodeling after MI}

IL-1 $\beta$ after MI, while active IL-1 $\beta$ secretion was only detected in M1M $\Phi$ but not M2M $\Phi$ which were polarized by the THP-1. In vitro, M2M $\Phi$ were subdivided into M2a (after exposure to IL-4 or IL-13), M2b (immune complexes in combination with IL-1 $\beta$ or LPS) and M2c (IL-10, TGF- $\beta$ or glucocorticoids) [32]. In our study, the THP- 1 was exposed to IL-4 and IL-13 to polarize the $\mathrm{M} 2 \mathrm{M} \Phi$, which were $\mathrm{M} 2 \mathrm{a}$ in fact. M2a mainly secret anti-inflammatory cytokines, such as IL-4 and IL-10, so there was no secretion of IL-1 $\beta$ in THP-1 polarized M2MФ. In contrast, CD206 characteristically expresses on all M2MФ, M2b are distinct from M2a since they produce significant amounts of IL-1 $\beta$ [32], so we detected coexpressed of M2M $\Phi$ and IL-1 $\beta$ in the myocardium post MI.

To clarify whether the infiltrating $M \Phi$ subsets, which release IL-1 $\beta$, participate in cardiac remodeling, we first detected the expression of its resource. As documented in the Lee report, the NLRP3 inflammasome is regulated by CaSR through $\mathrm{Ca}^{2+}$ and plays critical roles in the molecular pathogenesis of cryopyrin-associated periodic syndromes [19]. Thus, we hypothesized that NLRP3 inflammasome activation by CaSR in MФ subsets participates in NLRP3 inflammasome activation and contributes to cardiac remodeling after MI. CaSR is expressed in THP-1-differentiated MФ [18] and the activation of the NLRP3 inflammasome promotes the release of IL- $1 \beta$ in $M \Phi$, whereas the expression of CaSR and NLRP3 inflammasome components in $\mathrm{p}-\mathrm{M} \Phi$ and $M \Phi$ subsets post-MI is not well understood. Our results first demonstrated that CaSR and intact NLRP3 inflammasome components were upregulated in both $\mathrm{p}-\mathrm{M} \Phi$ and $\mathrm{M} \Phi$ subsets in post-MI myocardium. While, we detected less $\mathrm{CD} 206^{+} \mathrm{Casp}-1^{+}$cells compared with $\mathrm{CD} 206^{+} \mathrm{NLRP}^{+}$and $\mathrm{CD}^{2} 06^{+} \mathrm{ASC}^{+}$cells which was consistent with the results we achieved from THP-1-polarized $M \Phi$, and consistent with the decreased secretion of IL-1 $\beta$ in THP-1-differentiated M2M $\Phi$. The results demonstrated that the CaSR/NLRP3 inflammasome played an essential role in M1M $\Phi$ but did not in M2MФ. This finding is in accord with the previous results reported by Pelegrin, with the exception that the intact NLRP3 inflammasome, the inhibition of ROS production and trapping of the inflammasome complex through intracellular clustering of actin filaments inhibit IL-1 $\beta$ release in mice p-MФ polarized M2MФ [33]. Moreover, in our study, IL-4 and IL-13 were used to induce THP-1-polarized M2MФ, it has been reported that IL-4/IL-13 downregulate caspase- 1 , which is responsible for the proteolytic cleavage of pro-IL-1 $\beta$ into its active mature form $[34,35]$.

CaSR senses changes in extracellular $\mathrm{Ca}^{2+}\left(\left[\mathrm{Ca}^{2+}\right]_{0}\right)$ and triggers an increase in $\left[\mathrm{Ca}^{2+}\right]_{\mathrm{i}}[36]$. Elevation of CaSR agonists commonly elicits $\left[\mathrm{Ca}^{2+}\right]_{i}$ signals through the interaction between CaSR and PLC $[37,18]$. Intracellular $\mathrm{Ca}^{2+}$ signalling is important for NLRP3 inflammasome activation induced by extracellular ATP [38]. U73122 induces a decrease in $\left[\mathrm{Ca}^{2+}\right]_{i}$. In our study, M1MФ which were pre-incubated with U73122 failed to evoke an increase of $\left[\mathrm{Ca}^{2+}\right]$ i' meanwhile, components of NLRP3 inflammasome, Casp- 1 and IL-1 $\beta$ were inhibited but not CaSR in the presence of U73122 indicating a role for PLC-stimulated $\mathrm{Ca}^{2+}$ signals in inflammasome activation. $\mathrm{Ca}^{2+}$ releases from the $\mathrm{ER}$, which is a specialized calcium-storing organelle, is critical to increase $\left[\mathrm{Ca}^{2+}\right]_{i:}$. TG inhibition of the ER ATP-ase transiently elevates $\left[\mathrm{Ca}^{2+}\right]_{\mathrm{i}}$; however, $\mathrm{Ca}^{2+}$ exhaustion can be induced by the continuous inhibition of the $\mathrm{Ca}^{2+}$ pump on the ER, which results in decreased $\left[\mathrm{Ca}^{2+}\right]_{i}$. This is the reason why the $\left[\mathrm{Ca}^{2+}\right]_{i}$ in M1MФ and components of NLRP3 inflammasome, Casp- 1 and IL- $1 \beta$ decreased instead of increasing their expression when TG were used. $\left[\mathrm{Ca}^{2+}\right]_{\mathrm{i}}$ increases when $\mathrm{IP}_{3}$ receptor-dependent calcium release from the ER is activated by the hydrolyzation of phosphatidylinositol 4,5-bisphosphate $\left(\mathrm{PIP}_{2}\right.$ ) transversion into $\mathrm{IP}_{3}$ and DAG; thus, 2-APB reduces $\left[\mathrm{Ca}^{2+}\right]_{\mathrm{i}^{*}}$. By use of the 2-APB, we detected the same results with U73122. These findings demonstrated for the first time that CaSR regulates the NLRP3 inflammasome through the PLC-IP ${ }_{3}$ pathway in THP-1-polarized M1MФ. Nevertheless, it remains to be elucidated whether the role of $\mathrm{Ca}^{2+}$ on NLRP3 inflammasome activation is direct or indirect.

It has been reported [39] that the activation of NLRP3 inflammasome relies on two signals in MФ: priming and triggering [40]. In our study, we have suggest that CaSR plays an essential role in the activation of NLRP3 inflammasome, namely the triggering but not the priming signal. These results consistent with the report of Rossol [41] and Lee [19]. 


\section{Cellular Physiology Cell Physiol Biochem 2015;35:2483-2500 \begin{tabular}{ll|l}
\cline { 2 - 2 } and Biochemistry & $\begin{array}{l}\text { DOI: 10.1159/000374048 } \\
\text { Published online: April 24, 2015 }\end{array}$ & $\begin{array}{l}\text { O 2015 S. Karger AG, Basel } \\
\text { www.karger.com/cpb }\end{array}$ \\
\cline { 2 - 3 }
\end{tabular} \\ Liu et al: Activation of CaSR/NLRP3 Inflammasome in M1MФ Contributes to Cardiac Remodeling after MI}

While, we also observed an increase of Pro-IL-1 $\beta$. In general, priming stimuli can include any whose receptor signaling results in the activation of the transcription factor NF- $\mathrm{kB}$, such as ligands for IL-1R I and the cytokine receptors TNFR1 and TNFR2 [42, 43]. The activation of CaSR of MФ not only induces the secretion of IL-1 $\beta$ but also the IL-1 $\alpha$ [41] and TNF- $\alpha$ [18]. So in order to clarify the issue that whether it is these cytokines secreted by CaSR activation of $M \Phi$ contribute to re-priming of the NRLP3 inflammasome by the cytokine receptors IL-1R I, TNFR1 and TNFR2 or not, further analysis are needed.

Sterile inflammation is mediated through the NLRP3 inflammasome [44], which is important in MI. NLRP3-KO [45] or NLRP3 siRNA [46] reduced apoptosis, infarct size, and cardiac dysfunction compared with wild-type mice during MI; however, no difference was observed between the ASC-KO and wild-type mice [47] in infarct size during MI. The reason for these differences between NLRP3-KO and ASC-KO is the lack of consideration of the circulating blood cells such as leukocytes [48] and the importance of the interaction of infiltrated leukocytes with cardiac fibroblasts and cardiomyocytes in the pathological process of MI. Cardiac fibrosis is important for cardiac remodeling [49]. Cardiac fibroblasts, which represent the largest class of cells that reside in the heart, are highly active cells that exhibit increased proliferative, migratory and secretory properties [50]. To clarify the influences of the CaSR/NLRP3 inflammasome of M1M $\Phi$ in cardiac remodeling after MI, we studied the interaction between $\mathrm{M} 1 \mathrm{M} \Phi$ and cardiac fibroblasts. The cardiac fibroblasts were cocultured with the SN of M1M by CaSR; these results were the first to demonstrate that IL-1 $1 \beta$ increased the phenotype transversion, collagen and ECM secretion of cardiac fibroblasts via IL-1 $\beta$-IL-1R. Furthermore, IL-1 signaling is essential for fibrogenic pathways in the healing infarct and may play an essential role in the pathogenesis of post-infarction remodeling [51] and IL-1RI deficiency protected from the development of adverse remodeling [52]. Thus, we first reported that the CaSR/NLRP3 inflammasome played a role in the promotion of cardiac remodeling after MI by the interaction between IL-1 $\beta$-IL-1R in M1M .

There is some limitations worth noting in our current study. First, we find evidence of the role of activation of the CaSR/NLRP3 inflammasome in M1MФ only by the pharmacologic inhibitor which have some limitations, such as off-target, by the means of systemic siRNAs of the CaSR and the NLRP3 inflammasome in M1MФ will resolve this question. Second, although we have provided the evidence that CaSR/NLRP3 inflammasome failed to function in M2MФ, it is really important to confirm the issue with the classic stumili LPS plus ATP or nigericin further in the future work. Third, to eliminate the effects of $М \Phi$ polarization and the difference between neonatal and adult cardiac fibroblasts, M1M $\Phi$ which are extracted from the myocardium after MI need to coculture with cardiac fibroblasts which are obtained from adult rats. Fourth, in our current study, it is lack of the evidence of the critical role of CaSR in vivo to clarify the role of CaSR/NLRP3 inflammasome in M1M $\Phi$ in cardiac remodeling post MI. So it is necessary that in vivo study should be performed further.

If NLRP3 inflammasome activation by CaSR in M1M $\Phi$ may serve as a common pathway in the fibrosis cascade, the inhibition of CaSR activation in M1MФ may attenuate cardiac remodeling. The contribution of CaSR/NLRP3 inflammasome in M1M $\Phi$ identified in this study is the first demonstration of an important role of CaSR in immune cells in heart disease.

In conclusion, the current findings represent the first study to test the hypothesis and provide evidence that the CaSR/NLRP3 inflammasome plays an essential role via the PLC-IP ${ }_{3}$ pathway in $\mathrm{M} 1 \mathrm{M} \Phi$ in the promotion of cardiac remodeling post-MI in rats but was inhibited in $M 2 M \Phi$. The results suggest that CaSR is a potential target for intervention for the prevention of cardiac remodeling following MI.

\section{Acknowledgments}

This study was supported by the National Natural Science Foundation of China (81370319, 81200235, 81200143), Natural Science Foundation of Heilongjiang Province 


\section{Cellular Physiology Cell Physiol Biochem 2015;35:2483-2500

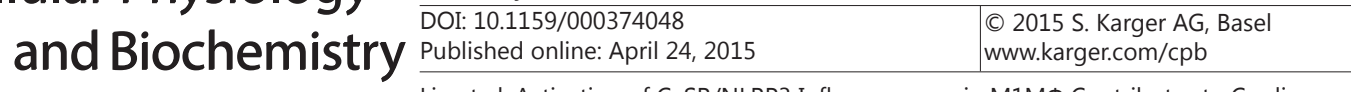 \\ Liu et al: Activation of CaSR/NLRP3 Inflammasome in M1M $\Phi$ Contributes to Cardiac Remodeling after MI}

(QC2012C015) and Graduate student innovation project in Heilongjiang province (YJSCX2012-238HLJ).

\section{Disclosure Statement}

None declared.

\section{Reference}

1 Entman ML, Smith CW: Postreperfusion inflammation: a model for reaction to injury in cardiovascular disease. Cardiovasc Res 1994;28:1301-1311.

2 Mehta JL, Li DY: Inflammation in ischemic heart disease: response to tissue injury or a pathogenetic villain? Cardiovasc Res 1999;43:291-299.

3 Lambert JM, Lopez EF, Lindsey ML: Macrophage roles following myocardial infarction. Int J Cardiol 2008;130:147-158.

4 Nahrendorf M, Pittet MJ, Swirski FK: Monocytes: protagonists of infarct inflammation and repair after myocardial infarction. Circulation 2010;121:2437-2445.

5 Guillén I, Blanes M, Gómez-Lechón MJ, Castell JV: Cytokine signaling during myocardial infarction: sequential appearance of IL-1 beta and IL-6. Am J Physiol 1995;269:R229-235.

6 Herskowitz A, Choi S, Ansari AA, Wesselingh S: Cytokine mRNA expression in postischemic/reperfused myocardium. Am J Pathol 1995;146:419-428.

7 Bujak M, Dobaczewski M, Chatila K, Mendoza LH, Li N, Reddy A, Frangogiannis NG: Interleukin-1 receptor type I signaling critically regulates infarct healing and cardiac remodeling. Am J Pathol 2008;173:57-67.

8 Van Tassell BW, Varma A, Salloum FN, Das A, Seropian IM, Toldo S, Smithson L, Hoke NN, Chau VQ Robati R, Abbate A: Interleukin-1 trap attenuates cardiac remodeling after experimental acute myocardial infarction in mice. J Cardiovasc Pharmacol 2010;55:117-122.

9 Abbate A, Van Tassell BW, Seropian IM, Toldo S, Robati R, Varma A, Salloum FN, Smithson L, Dinarello CA: Interleukin-1beta modulation using a genetically engineered antibody prevents adverse cardiac remodelling following acute myocardial infarction in the mouse. Eur J heart Fail 2010;12:319-322.

10 Toldo S, Mezzaroma E, Van Tassell BW, Farkas D, Marchetti C, Voelkel NF, Abbate A: Interleukin-1 $\beta$ blockade improves cardiac remodelling after myocardial infarction without interrupting the inflammasome in the mouse. Exp Physiol 2013;98:734-745.

11 Kate Schroder, Jurg Tschopp: The Inflammasomes. Cell 2010;140:821-832.

12 Fayyaz SS, Yasunori Ogura, Marian Szczepanik, Lara-Tejero M, Lichtenberger GS, Grant EP, Bertin J, Coyle AJ, Galán JE, Askenase PW, Flavell RA: Critical Role for NALP3/CIAS1/Cryopyrin in Innate and Adaptive Immunity through Its Regulation of Caspase-1. Immunity 2006;24:317-327.

13 Sandanger $\emptyset$, Ranheim T, Vinge LE, Bliksøen M, Alfsnes K, Finsen AV, Dah CP, Askevold ET, Florholmen G, Christensen G, Fitzgerald KA, Lien E, Valen G, Espevik T, Aukrust P, Yndestad A: The NLRP3 inflammasome is up-regulated in cardiac fibroblasts and mediates myocardial ischemia-reperfusion injury. Cardiovasc Res 2013;99:164-174.

14 Brown EM, Gamba G, Riccardi D, Lombardi M, Butters R, Kifor O, Sun A, Hediger MA, Lytton J, Hebert S: Cloning and characterization of an extracellular $\mathrm{Ca}(2+)$-sensing receptor from bovine parathyroid. Nature 1993;366:575-580.

15 Brown EM, Vassilev PM, Quinn S, Hebert SC: G-protein-coupled, extracellular Ca2+ -sensing receptor: a versatile regulator of diverse cellular functions. Vitam Horm 1999;55:1-71.

16 Lin KI, Chattopadhyay N, Bai M, Alvarez R, Dang CV, Baraban JM, Brown EM, Ratan RR: Elevated extracellular calcium can prevent apoptosis via the calcium-sensing receptor. Biochem Biophys Res Commun 1998;249:325-331.

17 Lu FH, Fu SB, Leng XN, Zhang X, Dong S, Zhao YJ, Ren H, Li H, Zhong X, Xu CQ, Zhang WH: Calcium-sensing Receptor in Cardiomyocyte Apoptosis via the Sarcoplasmic Retiuclum and Mitochondrial Death Pathway in Cardiac hypertrophy and heart Failure. Cell Physiol Bilchem 2013;31:728-743. 


\section{Cellular Physiology Cell Physiol Biochem 2015;35:2483-2500 \begin{tabular}{ll|l}
\cline { 2 - 2 } and Biochemistry & $\begin{array}{l}\text { DOI: 10.1159/000374048 } \\
\text { Published online: April 24, 2015 }\end{array}$ & $\begin{array}{l}\text { O 2015 S. Karger AG, Basel } \\
\text { www.karger.com/cpb }\end{array}$ \\
\cline { 2 - 3 }
\end{tabular} \\ Liu et al: Activation of CaSR/NLRP3 Inflammasome in M1M $\Phi$ Contributes to Cardiac Remodeling after MI}

18 Xi YH, Li HZ, Zhang WH, Wang LN, Zhang L, Lin Y, Bai SZ, Li HX, Wu LY, Wang R, Xu CQ: The functional expression of calcium-sensing receptor in the differentiated THP-1 cells. Mol Cell Biochem 2010;342:233240.

19 Lee GS, Subramanian N, Kim AI, Aksentijevich I, Goldbach-Mansky R, Sacks DB, Germain RN, Kastner DL, Chae JJ: The calcium-sensing receptor regulates the NLRP3 inflammasome through Ca2+ and cAMP. Nature 2012;492:123-127.

20 Huang NF, Sievers RE, Park JS, Fang Q, Li S, Lee RJ: A rodent model of myocardial infarction for testing the efficacy of cells and polymers for myocardial reconstruction: Nat Protoc 2006;1:1596-1609.

21 Wang YL, Malik AB, Sun Y, Hu S, Reynolds AB, Minshall RD, Hu Gl: Innate immune function of the adherents junction protein p120-catenin in endothelial response to endotoxin. J Immunol 2011;186:3180-3187.

22 Huang XR, Chung AC, Yang F, Yue W, Deng C, Lau CP, Tse HF, Lam JY: Smad3 mediates cardiac and fibrosis in angiotensin II-induced hypertensive cardiac remodeling. Hypertension 2010;55:1165-1171.

23 Matsuura M, Saito S, Hirai Y, Okamua H: A pathway through interferon-gamma is the main pathway for induction of nitric oxide upon stimulation with bacterial lipopolysaccharide in mouse peritoneal cells. Eur J Biochem 2003;270:4016-4025.

24 Tjiu JW, Chen JS, Shun CT, Lin SJ, Liao YH, Chu CY, Tsai TF, Chiu HC, Dai YS, Inoue H, Yang PC, Kuo ML, Jee SH: Tumor-associated macrophage-induced invasion and angiogenesis of human basal cell carcinoma cells by cyclooxygenase-2 induction. J Invest Dermatol 2009;129:1016-1025.

25 Tomoko Satomi, Mikako Ogawa, Ikuo Mori, Ishino S, Kubo K, Magata Y, Nishimoto T: Comparison of Contrast Agents for Atherosclerosis Imaging Using Cultured Macrophages: FDG Versus Ultrasmall Superparamagnetic Iron Oxide. J Nucl Med 2013;54: 999-1004.

26 Olson ER, Shamhart PE, Naugle JE, Meszaros JG: Angiotensin II-induced extracellular signal-regulated kinase $1 / 2$ activation is mediated by protein kinase $\mathrm{c}$ delta and intracellular calcium in adult rat cardiac fibroblasts. Hypertension 2008;51:704-711.

27 Ieda M, Tsuchihashi T, Ivey KN, Ross RS, Hong TT, Shaw RM, Sricastava D: Cardiac fibroblasts regulate myocardial proliferation through beta1 integrin signaling. Dev Cell 2009;16:233-244.

28 Sun B, Huo R, Sheng Y, Li Y, Xie X, Chen C, Liu HB, Li N, Li CB, Guo WT, Zhu JX, Yang BF, Dong DL: Bone morphogenetic protein-4 mediates cardiac hypertrophy, apoptosis, and fibrosis in experimentally pathological cardiachypertrophy. Hypertension 2013;61:352-360.

29 Tsujita K, Kaikita K, Hayasaki T, Honda T, Kobayashi H, Sakashita N, Suzuki H, Kodama T, Ogawa H, Takeya M: Targeted deletion of class a macrophage scavenger receptor increases the risk of cardiac rupture after experimental myocardial infarction. Circulation 2007;115:1904-1911.

30 Squadrito F, Altavilla D, Squadrito G, Campo GM, Arlotta M, Arcoraci V, Minutoli L, Serrano M, Saitta A, Caputi AP: 17beta-oestradiol reduces cardiac leukocyte accumulation in myocardial ischaemia reperfusion injury in rat. Eur J Pharmacol 1997;335: 185-192.

31 Yan X, Anzai A, Katsumata Y, Matsuhashi T, Ito K, Endo J, Yamamoto T, Takeshima A, Shinmura K, Shen W, Fukuda K, Sano M: Temporal dynamics of cardiac immune cell accumulation following acute myocardial infarction. J Mol Cell Cardiol 2013;62:24-35.

32 Martinez FO, Sica A, Mantovani A, Locati M: Macrophage activation and polarization. Front Biosci 2008;13:453-461.

33 Pelegrin P, Surprenant A: Dynamics of macrophage polarization reveal new mechanism to inhibit IL-1beta release through pyrophosphates. EMBO J 2009;28:2114-2127.

34 Cerretti DP, Kozlosky CJ, Mosley B, Nelson N, Van Ness K, Greenstreet TA, March CJ, Kronheim SR, Druck T, Cannizzaro LA, Huebner K, Black RA: Molecular cloning of the interleukin-1 beta converting enzyme. Science 1992;3 256:97-100.

35 Thornberry NA, Bull HG, Calaycay JR, Chapman KT, Howard AD, Kostura MJ, Miller DK, Molineaux SM, Weidner JR, Aunins J, Elliston KO, Ayala JM, Casano FJ,Chin J, Ding GJF, Egger LA, Gaffney EP, Limjuco G, Palyha OC, Raju SM, Rolando AM, Salley JP, Yamin TT,Lee TD, Shively JE, MacCross M, Mumford RA, Schmidt JA, Toccill MJ: A novel heterodimeric cysteine protease is required for interleukin-1 beta processing in monocytes. Nature 1992;30 356:768-774.

36 Wang R, Xu C, Zhao W, Zhang J, Cao K, Yang B, Wu L: Calcium and polyamine regulated calcium-sensing receptors in cardiac tissues. Eur J Biochem 2003;270:2680-2688.

37 Hofer AM, Brown EM: Extracellular calcium sensing and signalling. Nature Rev Mol. Cell Biol 2003;4:530538. 


\section{Cellular Physiology Cell Physiol Biochem 2015;35:2483-2500 \begin{tabular}{ll|l} 
and Biochemistry & $\begin{array}{l}\text { DOI: 10.1159/000374048 } \\
\text { Published online: April 24, 2015 }\end{array}$ & $\begin{array}{l}\text { O 2015 S. Karger AG, Basel } \\
\text { www.karger.com/cpb }\end{array}$ \\
\cline { 2 - 3 }
\end{tabular} \\ Liu et al: Activation of CaSR/NLRP3 Inflammasome in M1MФ Contributes to Cardiac Remodeling after MI}

38 Murakami T, Ockinger J, Yu J, Byles V, McColl A, Hofer AM, Horng T: Critical role for calcium mobilization in activation of the NLRP3 inflammasome. Proc Natl Acad Sci USA 2012;109:11282-11287.

39 Netea MG, Nold-Petry CA, Nold MF, Joosten LA, Opitz B, van der Meer JH, van de Veerdonk FL, Ferwerda G, Heinhuis B, Devesa I, Funk CJ, Mason RJ,Kullberg BJ, Rubartelli A, van der Meer JW, Dinarello CA: Differential requirement for the activation of the inflammasome for processing and release of IL-1 in monocytes and macrophages. Blood 2009;113:2324-2335.

40 Latz E, Xiao TS, Stutz A: Activation and regulation of the inflammasomes. Nat Rev Immunol 2013;13:397-411.

41 Rossol M, Pierer M, Raulien N, Quandt D, Meusch U, Rothe K, Schubert K, Schöneberg T, Schaefer M, Krügel U, Smajilovic S, Bräuner-Osborne H, Baerwald C, Wagner U: Extracellular Ca2+ is a danger signal activating the NLRP3 inflammasome through G protein-coupled calcium sensing receptors. Nat Commun 2012;3:1329.

42 Bauernfeind FG, Horvath G, Stutz A, Alnemri ES, MacDonald K, Speert D, Fernandes-Alnemri T, Wu J, Monks BG, Fitzgerald KA, Hornung V, Latz E: NF-kB activating pattern recognition and cytokine receptors license NLRP3 inflammasome activation by regulating NLRP3 expression. J Immunol 2009;183:787-791.

43 Franchi L, Eigenbrod T, Núñez G: TNF- $\alpha$ Mediate Sensitization to ATP and Silica via the NLRP3 Inflammasome in the Absence of Microbial Stimulation. J Immunol 2009;183:792-796.

44 Masafumi Takahashi: NLRP3 in myocardial ischemia reperfusion injury: inflammasomes-dependent or -independent role in different cell type. Cardiovasc Res 2013;99:4-5.

45 Sandanger $\emptyset$, Ranheim T, Vinge LE, BliksØen M, Alfsnes K, Finsen AV, Dahl CP, Askevold ET, Florholmen G, Christensen G, Fitzgerald KA, Lien E, Valen G,Espevik T, Aukrust P, Yndestad A: The NLRP3 inflammasome is up-regulated in cardiac fibroblasts and mediates myocardial ischaemia-reperfusion injury. Cardiovasc Res 2013;99:164-174.

46 Mezzaroma E, Toldo S, Farkas D, Seropian IM, Van Tassell BW, Salloum FN, Kannan HR, Menna AC, Voelkel $\mathrm{NF}$, Abbate A: The inflammasome promotes adverse cardiac remodeling following acute myocardial infarction in the mouse. Proc Natl Acad Sci USA 2011;108:19725-19730.

47 Kawaguchi M, Takahashi M, Hata T, Kashima Y, Usui F, Morimoto H, Izawa A, Takahashi Y, Masumoto J, Koyama J, Hongo M, Noda T, Nakayama J, Sagara J, Taniguchi S, Ikeda U: Inflammasome activation of cardiac fibroblasts is essential for myocardial ischemia/reperfusion injury. Circulation 2011;123:594-604.

48 Mezzaroma E, Toldo S, Abbate A: Role of NLRP3 (cryopyrin) in acute myocardial infarction. Cardiovasc Res 2013;99:225-226.

49 Swynghedauw B: Molecular mechanisms of myocardial remodeling. Physiol Rev 1999;79:215-262.

50 Manable I,Shindo T, Nagai R: Gene Expression in Fibroblasts and Fibrosis:Involvement in Cardiac hypertrophy. Circ Res 2002;91:1103-1113.

51 Bujak M, Dobaczewski M, Chatila K,Mendoza LH, Li N, Reddy A, Frangogiannis NG: Interleukin-1 receptor type I signaling critically regulates infarct healing and cardiac remodeling. Am J Pathol 2008;173:57-67.

52 Frangogiannis NG: The immune system and cardiac repair. Pharmacol Res 2008;58:88-111. 